\title{
Revisiting Ubuntu in the Midst of a Violent Conflict: Reflections on the Marikana Tragedy in South Africa
}

\author{
Tembeka Ngcebetsha, Nomazizi Jamela \\ Freedom Park, Salvokop, Pretoria, South Africa
}

\begin{abstract}
South Africa comes from a bitter past of gross inequalities and human rights abuses suffered by the majority of Africans as a result of the colonial and apartheid legacy. When apartheid was dismantled in 1994, through the spirit of reconciliation which was spearheaded by the country's late and former President, Mr. Nelson Rolihlahla Mandela, the country was transformed into a democracy where citizens opted to live together on the basis of equality and mutual respect for each other. The "New" South Africa immediately raised hope for change in the hearts of the majority, whose human rights were previously violated; who thought that the new dispensation would immediately bring improvements in their socioeconomic conditions. Based on the conflict perspective, this paper critically reflects on the recent case of violent conflict in South Africa known as the Marikana tragedy, to explore the efficacy of fostering meaningful reconciliation in the midst of a violent conflict. Through interviews carried out with survivors and wives of the deceased victims in October 2014, the paper demonstrates how the South African government has failed to meet the post-apartheid expectations, but instead, continues to serve the interests of capital at the expense of the majority of people whose working and living conditions have not improved 20 years into democracy. By interrogating their general understanding of democracy and reconciliation strategies used to address the conflict both by the government and the owners of capital, the paper concludes that meaningful reconciliation is a complex process that will take many more years than anticipated. It requires not only urgent redress of socio-economic imbalances through the implementation of the new National Development Plan (NDP), but also the implementation of carefully crafted conflict resolution strategies that are embedded in the application of Ubuntu principles by all those involved in the conflict.
\end{abstract}

Keywords: reconciliation, social cohesion, nation building, inequalities, Ubuntu, conflict, restorative justice, national development plan

\section{Introduction}

South Africa comes from a history of decades of deprivation, enforced division, gross inequalities, oppression and sustained conflict as a result of colonial and apartheid legacy which robbed many South Africans of basic human rights and freedom. As a form of resistance, South Africans engaged in different forms of the liberation struggle and in 1994, achieved democracy through a miraculous act of reconciliation which was spearheaded by the country's late and former President, Mr. Nelson Rolihlahla Mandela (hereafter referred to by his clan name, "Madiba"), where citizens opted to live together on the basis of equality and mutual

Tembeka Ngcebetsha, Senior Researcher, Department of Heritage and Knowledge, Freedom Park.

Nomazizi Jamela, Researcher, Department of Heritage and Knowledge, Freedom Park. 
respect for each other. Madiba's act of reconciliation was made possible through his application of the philosophy of Ubuntu - an African strategy based on humility - that united the nation under conditions that were extremely challenging. Since then, South Africans expected reconciliation to bring change, not only politically, but also positive improvements in their socio-economic conditions; and change they must receive to reclaim the freedom and humanity they voted for 20 years ago.

Using the Marxist conflict perspective, the paper critically reflects on the recent violent conflict in South Africa known as the Marikana tragedy, to demonstrate the extent to which the South African democratic government has lived or not lived to its post-apartheid expectations of providing meaningful reconciliation to the nation. It argues that attaining a truly reconciled, free, united, non-racial and non-sexist society in a country that is still faced with socio-economic challenges of poverty, inequalities and unemployment is a complex process that will take many more years than anticipated. It requires not only radical socio-economic transformation through the implementation of the new National Development Plan (NDP) but also the implementation of carefully crafted conflict resolution strategies that are embedded in the application of the philosophy of Ubuntu by all those involved in the conflict.

We begin the paper by clearly stating the problem, and locating it within a conceptual framework that is based on the Marxist conflict theory, to demonstrate how class and power continue to take the centre stage in addressing contemporary conflict situations such as the Marikana tragedy in South Africa. This is followed by a general historical overview of industrial strikes in South Africa after which an overview of the Marikana strike which led to the tragedy that killed 34 miners on 16 August 2012 is given. Particular focus is on what caused the tragedy from the perspective of the strikers and family members of the deceased, as well as views from deliberations generated at the Marikana Farlan Commission. The Marikana conflict is interrogated within the broader national reconciliation and social cohesion programme in the country, to expose the disjuncture between theory and practice - the extent to which the democratic government has failed to live to its post-apartheid expectations of providing meaningful reconciliation to the nation.

\section{Statement of the Problem}

The triple effects of the challenges currently faced by the overwhelming majority of South Africans, 20 years into democracy, is a very serious issue that needs urgent redress. Moreover, the extreme wealth and ostentatious lifestyles of the elite (government officials and owners of capital), some of whom were apartheid perpetrators and/or benefactors, and the rising emergence of the black middle class, all in the midst of dire poverty and inequalities experienced by the overwhelming majority of the population generate deep anger and resentment ${ }^{1}$ that often resonate in violent protests. It seems that reconciliation strategies used both by the government and owners of capital such as Lonmin mine owners, to address worker's needs, as well as to resolve the strike and its aftermath, still serve the interests of capital at the expense of the majority of people whose conditions have not changed 20 years into democracy; and have departed from the application of Ubuntu — an African solution to solving problems — as would have been applied by Madiba.

\section{Theoretical Framework}

The paper is foregrounded on the Marxist conflict theory which focuses on political, social and material inequality between fragmented social groups in a capitalist system that compete with each other for social and economic resources. For Karl Marx, history is a process of conflict between segments or classes of society with

\footnotetext{
${ }^{1}$ Johann Maree, chairperson of the Western Cape Branch of the Industrial Relations Association of South Africa (IRASA).
} 
unequal power. Because the groups have different interests, conflict arises as they struggle to maximize their share of the limited resources that exist within industry and the economic segment of society (Wolff, n.d.). Class conflict or class struggle is the tension or antagonism which exists in society due to competing socio-economic interests and desires between people of different classes ${ }^{2}$. However, the two groups become interdependent on each other, constituted to protect and further the aims of the Capital Elite who usually are also the Ruling Elite, and therefore function according to certain rules, whether democratic or not, so that they could continue to feed off each other.

The existing classes in South Africa and how they relate to each other are clear examples of how the conflict theory is applied in a capitalist system. In the Marikana situation, the highest echelon is the capital elite/class, the owners of industry and capital, which is represented by Lonmin owners. The Ruling Elite [African National Council (ANC) politicians], although totally separate from the Capital Elite, controls the levers of government with the support and approval of the Capital Class (Dube, 2012). The Middle Class does the bidding of both the Capital and the Ruling Classes. This class is beholden to both the Capital and Ruling Elites because its members survive only on jobs and credit dished out and regulated by the two classes. Although they are given relative freedom to be vocal to a point where they think they are the most important, they have limited power (Dube, 2012). At the bottom is the majority working class that keeps the country going through their supply of labor. This class is the most invulnerable with their strongest weapon being that neither of the classes want to be pushed down to their level. Although no one wants to belong to the working class, it would seem that this is where power lies. All the classes usually relate to each other according to the established rules and are all kept in check by the accepted norms of do's and don'ts. The Marikana strike demonstrate (albeit horribly) how powerful the working class can be and how much power they hold when they disregard the rules designed to keep them in check.

However, in the 20th century, due in large part to the work of C. Wright Mills, the focus of conflict theory shifted to disparate arenas of class, race and religion to the umbrella notion of power, especially power and social control which is in the hands of elites. The conflict theory emphasizes the role of coercion and power exercised by those with the greatest political, economic, and social resources (both ruling elite and capital), in producing social order which is maintained by domination. According to Mills (1956), one of the results of conflict between people with competing interests and resources is the creation of a social structure i.e., relatively fixed institutions and norms of society that heavily influence, consciously or not, peoples' everyday behavior, which is also under the control of the elite, who generally oppose the interests of the non-elite ${ }^{3}$. It is in the process of exercising power over others that inequality is produced, resulting in different forms of power struggles by poor people who ultimately become aware of their own exploitation. Inequality exists because those in control of a disproportionate share of society's resources actively use their power to defend their advantages ${ }^{4}$. From a Marxist perspective, it is through the class struggle that a radical social change for the majority can be achieved. In the South African situation, specifically, in the Marikana case, the ruling elite (ANC) is very close to the mine owners (capital) and as will be indicated later, they have continuously failed to protect the interests of the working class.

Unlike functionalists who defend the status quo, avoid social change, by believing that people cooperate to

\footnotetext{
${ }^{2}$ Retrieved from http://en.wikipedia.org/wiki/Class_conflict

3 Retrieved from http://en.wikipedia.org/wiki/Class_conflict

${ }^{4}$ Retrieved from http://sociology.about.com/
} 
effect social order; and through consensus and conformity, people unite around common interests, the conflict theorists challenge the status quo, encourage social change (even when this means social revolution), and believe that the rich and powerful people force social order on the poor and the weak. This implies that the masses are not bound to the organization by their shared values, but by coercion at the hands of those in power. For example, in the case of Marikana, conflict theorists may interpret the view of a mine shareholder such as Cyril Ramaphosa ${ }^{5}$ to exert pressure on the strikers and the ensuing actions of the police following that instruction as self-serving rather than beneficial for workers. In this regard, the shooting by the police at the striking miners could be seen as protecting the interests of the National Executive Committee (NEC). Every now and then events like Marikana will come along and disturb the equilibrium but this is quickly dealt with by the joining of forces of the other classes to pull the dissenting one back into line (Dube, 2012).

When the majority of South Africans obtained the franchise in 1994, a democratic government was established which emerged with the truth and reconciliation process which was meant to promote national unity and reconciliation. As will be discussed, the unfinished business of the Truth and Reconciliation Commission (TRC), can be alluded to the fact that this process operated soon after the new democratic government was established, and was thus primarily focused on reconciling political injustices and to some extent, social injustices rather than economic injustices ${ }^{6}$. Although the TRC succeeded to contextualize all human rights violations within a framework in which fundamental human rights such as socio-economic inequality, decent education and adequate health care were denied (Hamber, 2002, pp. 65-67), it failed to make a link between structural violations of apartheid (systematic poverty or inequalities) and direct human violations suffered by those who testified (Hamber, 2002, p. 69); it thus failed to provide a more racialized and structural economic analysis of South Africa. Because of its limited approach to addressing social injustices, it would seem that the TRC played an integral role in defining the existing class content in the New South Africa, which translated into gross inequalities (especially racial) between the haves and have not's, which have continued to persist even in the post-apartheid period.

\section{Reconciliation Conceptualized}

Reconciliation is the process through which a society moves from a divided past (not necessarily through the admission of guilt) by means of improved communication and better understanding between groups, towards greater cooperation and coexistence at both individual and political level (Hamber, 2002, p. 66). De Gruchy (2002) defines reconciliation as a "mutual attempt to heal and overcome enmities, build trust and relationships and develop a shared commitment to the common good" (p. 15). The process presupposes a fundamental shift in personal and power relations (Gruchy, 2002, p. 25), which should lead to a change in relationship between the beneficiaries of apartheid and those disadvantaged by it ${ }^{7}$.

In practice, resolving a violent conflict such as the one that occurred in Marikana requires readiness by both survivors and perpetrators to leave the tyranny of violence, human rights violation, and fear behind so that peaceful coexistence can occur. Survivors in this paper, refer to the victims of the Marikana tragedy, i.e., striking miners and family members of the deceased. As a backward-looking operation, reconciliation should bring about the personal healing of survivors, the reparation of past injustices, the building or rebuilding of

\footnotetext{
${ }^{5}$ Cyril Ramaphosa is the Deputy President of the Republic of South Africa and was once a leading anti-apartheid activist and a former leader of the National Union of Mineworkers (NUM).

${ }^{6}$ Pumla Gobodo-Madikizela on SAFM radio interview.

7 TRC Report, Volume 5.
} 
non-violent relationships between individuals and communities, and the acceptance by the former parties to a conflict of a common vision and collective understanding of the past (Bloomfield, Barnes, \& Huyse, 2003, p. 19). In its forward-looking dimension, the reconciliation process should enable both the victims and perpetrators to get on with life and, at the level of society, to allow for the establishment of a civilized political dialogue and an adequate sharing of power (Bloomfield, Barnes, \& Huyse, 2003).

This paper will interrogate the extent to which change or lack of change in relationship between beneficiaries of apartheid and those who were disadvantaged continued to benefit the interests of capital, while workers remained impoverished; and thus contributed to conflict that led to the violent protest strike in Marikana. In this regard, the strike is understood as a consequence of failing to effect socio-economic changes in a country that is undertaking a national reconciliation agenda, the strategies of which seem to have overlooked the application of Ubuntu principles — an African way of addressing conflict situations.

\section{Ubuntu as a Reconciliation and Nation Building Strategy}

A human being is made of both spiritual and material aspects, where the material being is the vehicle of the spiritual aspect (Motsheka, 2012, p. 28). Spiritual humanism - Ubuntu, Botho, Utu, Vunhu —is an aspect of humanity that nurtures holistic human development, but which has been undermined as a result of the birth of secular humanism during the 18th and 19th centuries (Motsheka, 2012). Ubuntu is one of the old principles of restorative justice used in African society-our common spiritual humanity which is derived from the "higher being" and its intrinsic quality (Motsheka, 2012, p. 32), and an important component of establishing meaningful reconciliation. Restorative justice is an African way of jurisprudence which is embedded in Ubuntu. Though emanating from southern Africa, the philosophy of Ubuntu exists in almost all indigenous societies. Motsheka defines the attributes of Ubuntu philosophy as human compassion, the spirit of sharing, mutual support, love and respect for the self and others, a virtuous life, human and social solidarity, equal treatment, freedom and justice for all as expressed in the maxim, "I am because we are" or "I am through others" (Umuntu ngumuntu ngabantu or motho ke motho ka batho). Literally, it means that we are one people because we derive our souls from one source and these souls are accompanied into their material bodies and upon the death, the soul returns to God or gods. Dr. Du Toit ${ }^{8}$ has a similar view of Ubuntu, as a quintessentially African moral approach to how people live with others. It prizes harmony and community whose qualities and form hinge on the ways and conditions in which people communicate (Du Toit, 2013). Motsei (2007 cited in Gutto, 2006) summed up Ubuntu as:

An ancient philosophy founded on the notion of communalism (I am because we are), driven by attributes such as truth, justice and compassion. The philosophy does not discriminate on the grounds of race, economic affluence social status or gender. It is a flow of life that is the same for every member of the human race. Ubuntu is not only tied to human life. It also concerns itself with respect for animals and the environment. The adoption of such a philosophy therefore seeks to create a balance between the self and others, as well as between the internal and external. (p. 10)

As a guide towards nation-building and peaceful coexistence, Ubuntu is often regarded as having positive consequences for transformation and development. Ubuntu is a philosophy that can assist in the reconstruction and rebuilding of societies which requires multifaceted transformations that include truth telling, forgiveness, justice and reparations. Questions asked in this paper will be around whether the moral prescripts of Ubuntu

\footnotetext{
${ }^{8}$ Dr. Du Toit is executive director of the Institute for Justice and Reconciliation based in Cape Town.
} 
were used in reconciling differences between workers, government, and Lonmin mine owners; as well as understanding the obligations this ethic places on reporters and media owners toward society.

\section{Historical Overview of Violent Protests in SA}

The culture of violence in South Africa is not new. Its roots can be traced far back in history in service delivery protests and various industrial strikes over the years which disrupted many lives and frequently destroyed property. The only difference with the recent violent conflicts is that they take longer with dire consequences, whereas the historical violent protests were shorter as the authorities would soon give in to the demands of the protesters and resolve the conflict in about three days the violence erupted. However, the unintended consequences of this would be the reinforcement of the message that it is only through violence that demands are met ${ }^{9}$.

Historically, workers have always used the strike weapon as the means to challenge the basis of their exploitation ${ }^{10}$. Evidence can be found from the 1946 African Miners' Workers' Strike which threatened the structure of the total society and profits of capital, to the defiance of the Native Labor Act by the African Tobacco Company in 1954 where workers were demanding increases in daily wages, to the 1958 strike by 3,800 African textile workers in Amato Textile Mills in Benoni, up to the 1973 Durban Strikes, and so on. Because of the nature of state repression during apartheid, issues involved in any single strike were often connected to the struggle against the whole social order, the entire ruling class, and not just to the individual employer ${ }^{11}$.

For most of that time, the South African Congress of Trade Unions (SACTU) and its affiliated unions, encouraged workers to boycott the machinery of the Native Labor Act, whether it was for higher wages and improved working conditions, union recognition or reinstatement of unjustly dismissed workers, were met with full force of the state. Throughout these strikes, African workers were and still continue to be faced with a united front of government and employers, often backed by the power of the police. These strikes were similar to "small scale civil wars" with "lorry-roads of police armed with batons, sten-guns and tear-gas bombs", where great pick-up vans arrive and all the strikers are arrested ${ }^{12}$.

With the formation of the Congress of South African Trade Unions (COSATU) in 1985, workers from companies such as the Frame Group in Durban came out in a series of wildcat strikes (illegal strikes), which marked the new phase of radical trade unionism. It is interesting to note that even then, the role of the media was biased against the workers, highlighting the threat of violence and calling for the restoration of law and order. But the apartheid state did not always respond with the kind of killings that are happening in recent years, probably because the strikes were in industrial areas. It would seem that in the Durban strikes, the media had painted the same idea of ignorant misled Zulu workers.

The De Doorns Farm Workers Strike, which occurred in the Western Cape Province on August 27, 2012 and spread to other areas, ${ }^{13}$ is another case in point. The strike was initiated by a group of largely female workers near De Doorns, who walked off the job without mediation by political parties, trade unions or NGOs. In January 2013, about 3,000 to 4,000 striking farm workers engaged in a peaceful march along the Western

\footnotetext{
9 Johann Maree is the chairperson of the Western Cape Branch of the Industrial Relations Association of South Africa (IRASA).

101946 African Mine Workers Strike. Retrieved from http://www.sahistory.org.za/topic/1946-african-mine-workers-strike

111946 African Mine Workers Strike. Retrieved from http://www.sahistory.org.za/topic/1946-african-mine-workers-strike

${ }^{12}$ Leon Levy, the former president of SACTU.

13 Western Cape 2012 Farm Workers' strike in http://en.wikipedia.org/
} 
Cape town of De Doorns down N1 freeway to demand that they be paid an increase in farm workers' minimum daily wage to R150 from R69 and a minimum of R80 per day in wages with immediate effect (Vecchiatto, 2013). The workers were demanding reasonable wages which were in par with the rising food prices, as food insecurity made it impossible for people to live on about R70 a day.

What is striking in the De Doors strike is the considerable police violence that accompanied it (Fogel, January 14, 2013). Three protesters were killed by police and a number of workers were fired at as a result of their participation in the strike (Fogel, January 30, 2013). The strike included road blockades, burning vineyards, some looting of shops, property damage estimated at R500,000.00 ${ }^{14}$, destruction of a packing shed, veld fires, damage to farming crops, burning of tyres in streets and throwing of stones. A clinic along the route of the march had to be closed as a result of threats with violence and intimidation against health workers. Furthermore, a policeman was hospitalized after being hit on the head by a stone thrown by a protester and 10 people were arrested for public violence and intimidation, and many were fired.

Interventions by the Agriculture Minister Tina Joemat-Pettersson, who tried to "restore relationships" between striking farm workers and farmers in order to save jobs did not succeed. She called for an end to the violent strike and also for interventions by the labor department to review the minimum wage for the entire agriculture sector and even took the matter to President Jacob Zuma on their behalf ${ }^{15}$. The strike was finally called off on 22 January $2013^{16}$.
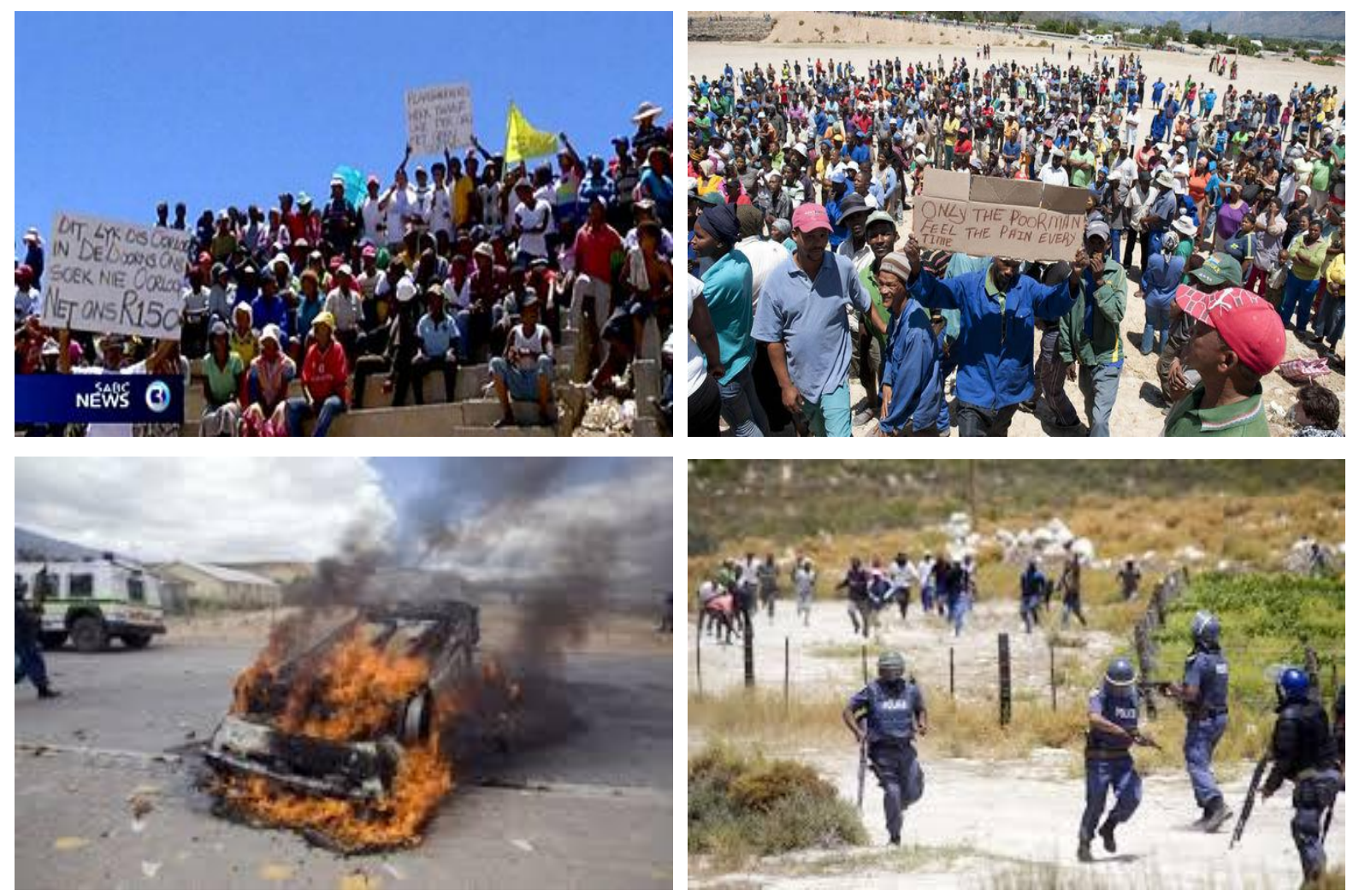

Figure 1. Striking farm workers, violence and the police in action.

\footnotetext{
14 According to municipal spokesperson Anette Radjoo.

15 Retrieved from http://www.bdlive.co.za/

${ }^{16}$ Farmworkers' strike may be over-but everyone's a loser, Rebecca Davis, 23 January 2013.
} 
The Marikana strike is no different from the rest of the violent protests demonstrated above, except that it took longer with severe damage on property, loss of lives, and many being injured. Below is an overview of the Marikana tragedy.

\section{The Marikana Tragedy}

The Marikana miners' strike or Lonmin strike dubbed by the press as the Marikana massacre, was a wildcat strike by workers who were protesting about wages and conditions at a mine owned by Lonmin in the Marikana area close to Rustenburg in $2012^{17}$. This is the massacre that occurred on 16 August 2012, when the South African police opened fire on striking miners at a Lonmin platinum mine and left 34 miners dead and 78 injured. Some describe the massacre which was preceded by 10 other deaths (two of which were police officers and two were security guards) during that week, as a "well organized, premeditated slaughter", which saw to the death of the majority of miners who were running from the police. ${ }^{18}$
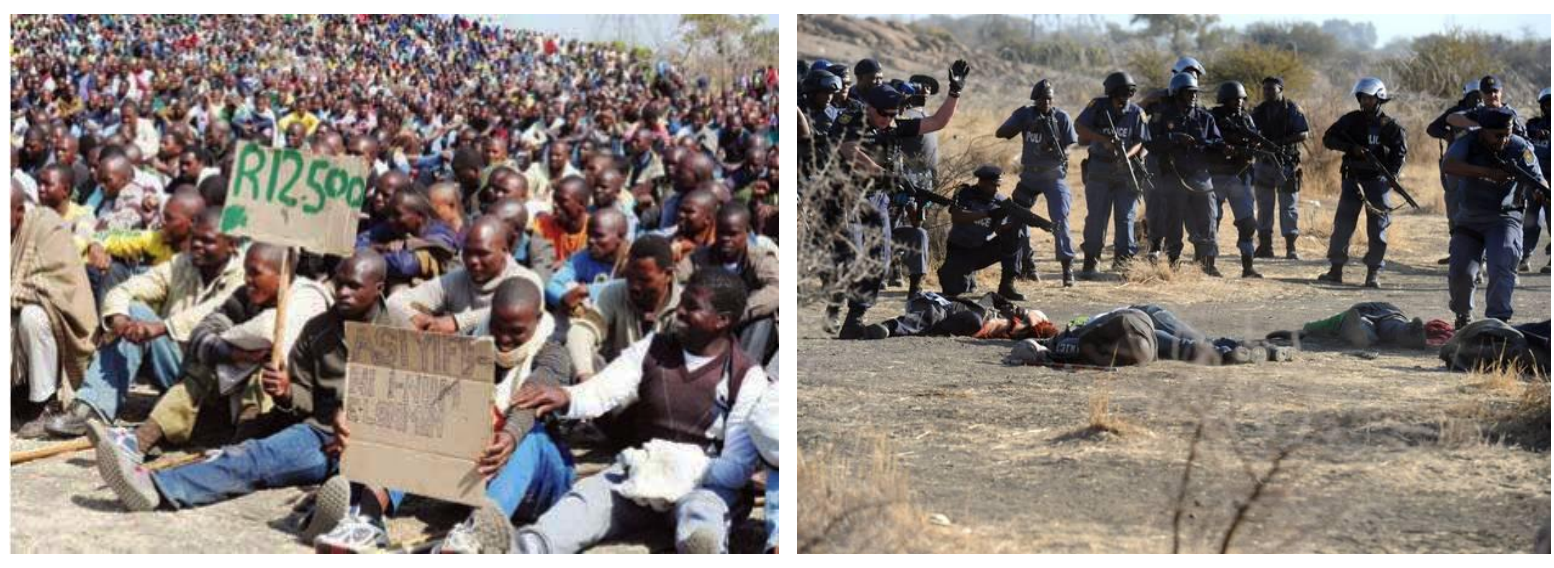

Figure 2. The striking miners and police forces in action.

The striking mine workers gathered nearby Nkanini Hill armed with spears, pangas and sticks, joined by a large group of women who were not employed by the mine but some of whom were also armed with knobkerries. It appears that there were "two scenes where the shootings occurred, which were condoned off properly"19 the koppie or where the police had placed the fence. Prof. Alexander (2012), who did research on the nature of the protest, visited the scene of the massacre and based on interviews with survivors and evidence, made the following analysis which is contrary to the official police view that the police opened fire in self-defense. Below is his analysis of the scene.

\section{How the Massacre was Planned and Carried Out}

The striking miners were surrounded by heavily armed police and soldiers, and they were shot at and some of them killed while fleeing from gunfire. Evidence indicates that the state forces were not "protecting themselves" against the miners, but participated in a well-organized, premeditated slaughter. The diagram below indicates a number of events that occurred, which are described below (Alexander, Sinwell, Lekgowa, Mmope, \& Xezwi, 2012):

\footnotetext{
${ }^{17}$ Marikana miner's strike. Retrieved from http://en.wikipedia.org/wiki/Marikana_miners'_strike

18 This theory has been adapted from the research conducted by a team of University of Johannesburg researchers, led by Sociology Professor Peter Alexander. In Sunday Independent of August 26, 2012.

19 According to Independent Police Investigative Directorate (IPID) spokesman Moses Dlamini. Retrieved from http://lists.fahamu.org/pipermail/debate-list/2012-August/031369.html
} 
(1) On the day of the killing, about 3,000 striking miners were gathered on and just below the "mountain" or the "koppie" (a small hill). Joseph Mathunjwa, president of their union, the Association of Mineworkers and Construction Union (AMCU), came and pleaded with them to leave to avoid a police attack but the miners refused.

(2) Within 15 minutes of Mathunjwa leaving, the police and army laid a razor wire, which was separating the strikers from the ENkanini informal settlement where many of them live. Casspirs (armoured cars), horses and water cannon moved up to encircle the workers.

(3) Some workers walked down to the razor wire to see if they could still get out through a gap. Witnesses say police near the "small koppie" opened fire on them, probably with rubber bullets. Some workers fled through a five-metre gap in the razor wire. They were met with a barrage of live fire from the police and many strikers died.

(4) Terrified strikers scattered in all directions, with a large number heading for cover by a koppie about 300 metres in the opposite direction from the wire. No cameras recorded this slaughter. But evidence such as remnants of blood remained, four days after the massacre and police markers showed where corpses were removed.

(5) Other strikers were killed as they fled across the fields. Some examples are marked on the map. Shots were fired from helicopters and some workers, heading for hillock, were crushed by Casspirs. We also saw patches of burned grass, which local workers claimed were remains of police fires used to obscure evidence of deaths.

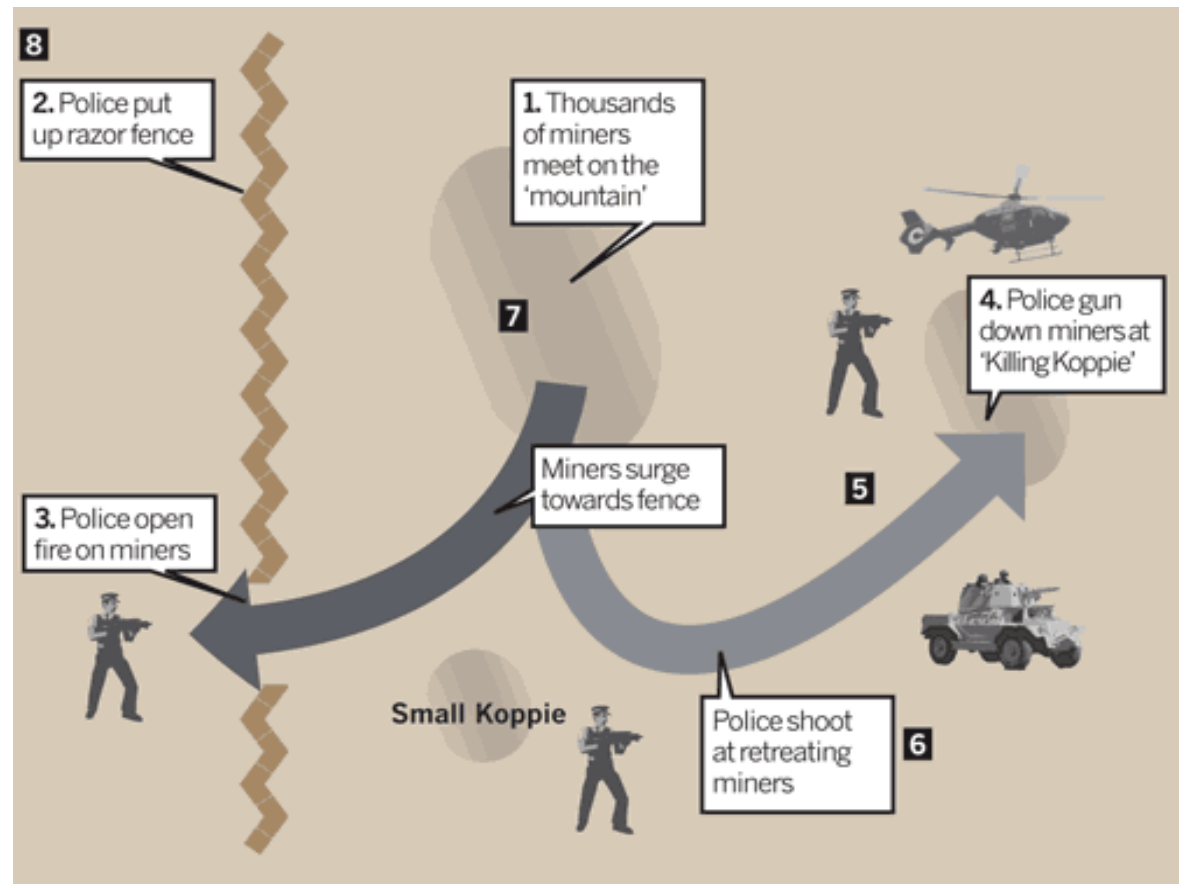

Figure 3. How the massacre was carried out.

The Marikana massacre represents the single most lethal use of force by South African security forces against civilians since 1960 Sharpeville Massacre, and the end of apartheid era ${ }^{20}$. The events illustrated above

\footnotetext{
${ }^{20}$ Marikana miners strike. Retrieved from http://en.wikipedia.org/wiki/Marikana_miners’_strike
} 
show that the Marikana tragedy was not just a story of hardship, violence and grief, but an indication that the striking miners were mere victims and not agents of their own future. The shock and horror of the massacre attracted a lot of international media attention, watched by millions of on TV with howls of anger and grief especially because no one wanted to take responsibility. ${ }^{21}$

Much controversy around the massacre emerged with the discovery that many striking miners were shot in the back, and some far from police lines. On 18 September, a resolution was however reached that striking miners had accepted $22 \%$ pay rise, a once off payment of R2,000 and that they would return to work on 20 September $2014^{22}$.

\section{Perspective From the Police}

It is reported that the police used live ammunition in response to firing with a shotgun by one of the workers. Although the workers appeared to have been "peacefully gathered", the police maintained that the workers fired first. According to information received by the Police Commissioner Phiyega, the crowd did not intend to leave peacefully on that day, and the police expected a violent outcome which led to the deployment of concertina wire barricades, water cannons, rubber bullets, stun grenades and tear gas to break the crowd $\mathrm{d}^{23}$. According to the South African Police Service, the miners refused a request to disarm and attacked them with firearms and dangerous weapons. The commissioner claimed that it was when the efforts to control the situation failed and the miners turned violent and attacked members of the SAPS, that the police used maximum force to protect themselves. In other words, they claim that the police fired in self-defence ${ }^{24}$.

\section{A Struggle Between Unions}

The events at Marikana have considerable political implications, and central to this is a struggle between various unions for members and influence ${ }^{25}$. The Lonmin strike is second to hit the platinum sector. It was preceded by a strike at Implant and before that at Angloplat. It seems that the strike occurred against the backdrop of antagonism between the ANC aligned National Union of Mineworkers (NUM) and its emerging rival Association of Mineworkers and Construction Union (AMCU), which was used by the workers as an outlet for their frustrations by NUM and Lonmin. In this sense, the Marikana strike and other protests were expected, and could be a source of a new movement in the making.

As illustrated above, during the strike, the workers stood not only against the police, but were also faced with dismissal threats from Lonmin, as well as labels from the media, that the strike was "illegal". This is against an official position that the strikes are not illegal in South Africa, they are either protected or unprotected. There was a strong view that NUM and COSATU rallied behind the ruling ANC - to stigmatize the strikers and the union. Meanwhile, the NUM had reportedly lost thousands of members to the more radical AMCU, which contributed to it being the largest member of South Africa's federation of trade unions. There were also other developments within NUM, to move workers from the union of coalface workers, to a union of white-collar above-ground technicians. It is these developments that led to the formation of the breakaway union - the AMCU, which comprised disgruntled members from NUM. Other reasons for the breakaway were

\footnotetext{
${ }^{21}$ Leonard Gentle, director of the International Labor Research and Information Group (South Africa)

22 Announcement by Bishop Jo Seoka of the South African Council of Churches, who was mediating a resolution to the conflict.

${ }_{23}$ Marikana miners strike. Retrieved http://en.wikipedia.org/wiki/Marikana_miners'_strike

${ }^{24}$ Marikana miners strike. Retrieved http://en.wikipedia.org/wiki/Marikana_miners,_strike

25 Retrieved from http://www.independent.co.uk/news/world/africa/marikana-mine-strikes-no-peace-and-reconciliation-18months-after- south-african-police-shot-and-killed-34-protesters-9022990.html
} 
due to succession battles within the ANC during that time, with NUM leadership campaigning for ANC President Jacob Zuma to win the second term. It therefore, seems that the emergence of AMCU, presented a direct challenge to the hegemony of NUM and of COSATU, which led to their disgraceful campaign of slandering the striking workers and their union as uneducated, Basotho or Eastern Cape Xhosas etc., while flogging the idea that an increase of R12, 500 was "unreasonable", without checking how much the rock drillers were actually earning (Dube, 2012).

\section{The Role of The Media}

The media's culpability in demonizing the striking workers has been reprehensible. Throughout, the media coverage was biased in support of the politicians and Lonmin. It gave space to stories of family members of the deceased workers and editorialized on Lonmin's practises. In addition to only quoting NUM sources for information of the strike, the media made no attempt to dig beneath the idea of manipulated workers and inter-union rivalry. Instead, its landerized workers, claiming that they were so open to manipulation that they believed any empty promises. This was against a clear position of taken by Lonmin workers, that they had made their choice - to become members of the AMCU and risk everything - including their lives - for a better future which was not well covered by the media. As will be shown, that during the strike up to its aftermath, where many miners lost their lives, the media demonstrated very little compassion for the workers. Many analysts and commentators seemed to have forgotten all about the people who actually died and their families in their reporting.

\section{The Marikana Commission}

After recognizing the depth of the effects of the massacre, President Jacob Zuma appointed the Marikana Commission of inquiry to investigate "matters of public, national and international concern" arising out of the tragic incidents at the Lonmin mine (Du Toit, 2013). The commission was to interrogate police, miners, union leaders, government employees and Lonmin employees about their conduct on the day, that would provide accurate, reliable information on how and why public order policing broke down, so as to prevent similar events from reoccurring. Given the socio-political climate that seemed conducive to heightened levels of public unrest, the commission's input was vital, in order to provide some sense of justice, primarily for direct victims of the tragedy, but also for the wider mining community where there was visible abject poverty. The commission began its work on 1 October 2014 and will be running until 14 November 2014.

Since the shooting, more evidence emerged that suggested that the police were preparing for a showdown with miners at the site, owned by the London-listed South African firm Lonmin. In response, senior officers ordered extra ammunition and the dispatch of mortuary vans in advance. Indeed, the inquiry heard that the police had fired at least 600 live rounds to disperse up to 3,000 striking miners, some of whom were armed with machetes and traditional weapons. However, what raised the stakes at the hearings were details of transcripts of conversations between a senior police official, Lieutenant General Zukiswa Mbombo, and an executive of the Lonmin company a day before the shooting during which, the police commander said she had been told by the police minister that Cyril Ramaphosa, a senior figure in the ANC and a Lonmin shareholder, to exert pressure ${ }^{26}$. This is why many activists say the event was no coincidence, it was clear that the police had prepared themselves for a day of violent encounters. "Given the fact that the police were on the back foot, it was even clearer that the massacre was premeditated and there was an expectation that some miners' lives would be

\footnotetext{
${ }^{26}$ Marikana miners strike. Retrieved from http://en.wikipedia.org/wiki/Marikana_miners’_strike
} 
lost" 27.

Others have described the Farlan commission, as more than an ably run judicial process, but a reminiscent of the Truth and Reconciliation process, as reflected in the Marikana commission's official motto: "Truth, Restoration, and Justice". Although there could be parallels between the two commissions, there are apparent differences. Most important, the TRC was designed to consolidate a complex political transition, and to guide the country through a transition, from a situation where human rights and the rule of law had been thoroughly compromised, to a much more credible and fair dispensation. Thus, it offered conditional amnesty, not as a step away from the rule of law, but rather as a step towards it.

During the proceedings, there were those who had no confidence in the credibility of the Commission, who thought it was the state's attempt to clear its role in the massacre. The miners believed that the commission was not prepared to hold the police chiefs or officials who ordered the crackdown accountable based on their claim that they were defending themselves against the armed miners. At the same time, the commission was not convinced of this, due to the seemingly fabricated evidence before the commission. By the time of writing this paper, the commission was still going on and would be submitting its final report at the end of March 2015.

\section{Accounts Given by Miners}

Five underground miners were interviewed in October 2014 to give an account of what happened during and after the strike with particular focus on efforts made to reconcile the victims (workers) in the aftermath. Just like many of the others working deep underground in the mines at Marikana, the interviewees were born and grew up in the Eastern Cape Province. Due to lack of opportunities, they were pushed towards the rich seams of Marikana, most of them through TEBA. This is how they describe events.

\section{Working and Living Conditions vs Wages}

Lack of employment opportunities for local youth, squalid living conditions, unemployment and growing inequalities contributed to the Lonmin strike ${ }^{28}$. The workers described the working conditions in the mines as very harsh and inhuman. Mr. Nzuza ${ }^{29}$ described a normal working day for the miners as supposedly eight to nine hours, but in reality, is considerably longer as follows:

The miner on his shift wakes up at 3 am to catch a bus to the pithead and then wait again for a cage to take them down into the mine. The hours for which they are paid start only when he reaches his machine deep underground. By the time they repeat the process again at the end of the shift, it can be $4 \mathrm{pm}$ before he reaches the metal-roofed room he rents.

All those interviewed concurred with Mr. Nzuza's analysis and believed that the miners' fight for justice was far from being over, precisely because the money paid to miners does not match their hard work and the conditions under which they work. A 26 year old man interviewed in October 2014, who did not want to state his name, added that:

The machine we use deep down is as big as a cow's head and too heavy and complex, much as a slight increase of $10 \%$ was given, the amount paid does not equal the pain we suffer.

\footnotetext{
${ }^{27}$ Comment by Rehad Desai, a filmmaker and activist. Retrieved from http://www.minersshotdown.co.za/

${ }_{28}$ Marikana miners strike. Retrieved from http://en.wikipedia.org/wiki/Marikana_miners'_strike

${ }^{29} \mathrm{Mr}$. Nzuza is one of the leaders of the striking miners who was front and centre when armed police decided to break up the protest. The 29 year old has been giving evidence to the commission of inquiry that is investigating the Marikana tragedy. Retrieved from http://www.independent.co.uk/news/world/africa/marikana-mine-strikes-no-peace-and-reconciliation -18-monthsafter-south-african-police-shot-and-killed-34-protesters-9022990.html
} 
That time we were earning four thousand rand but after deductions we get three thousand a month, what is that? The saddest part was that we did not get what we were promised to get by the Lonmin mine owners, they lied to us by saying we will get our $22 \%$ we demanded, whereas when we arrived back to work it was a different story ${ }^{30}$.

Mr. Nzuza concurred with the view that although the money had increased slightly, everything else had stayed the same i.e., as promised, they were hoping for both better working and living conditions. The miners therefore, think the amount of 12,500 they were promised is just a dream.

From this description, it seems that the benefits of mining are not meeting the workers needs or of surrounding communities. The wages do not consider the circumstances of the majority of workers, most of whom are migrant workers from extended family structures where a single worker does not only feed his immediate family in Markana but also feeds a number of family members at home. Thousands of families from across South Africa and beyond its borders are drawn to Marikana due to lack of employment.

The living conditions workers live are wretched, in camps and shacks set out in the shadow of the mines, which become challenged during rainy days when the rutted, unpaved tracks turn to mud. They are without electricity, with some children suffering from chronic illnesses due to sewage spills caused by broken drainage. In addition, mine workers are exposed to a variety of safety hazards: falling rocks, dust, intensive noise, fumes and high temperatures, among others ${ }^{31}$. The low wages they receive, compared to the high profits they generate for the owners, illustrate the extent of worker exploitation in the mines, and a cause for concern, which led to the conflict and the subsequent violent protest.

When the interviewees were asked how the strike started, they first made reference to the Lonmin strikes of 2012, which took place for three months up to the devastating one which lasted for about six weeks and left 34 mine workers dead and affected the community negatively. Mr. Lulamile Khali explains the background of the strike:

Originally the strike was initiated by the Rock Drifters (RDOs) in Lonmin mine, they started by passing their grievances to the Lonmin headquarters but they were not heard. They mobilized other workers to join them in a strike and everyone did. This was to put pressure on the management. The RDOs organized about three strikes that year. These strikes started without any union leadership's assistance. We did not have a legal union and we were also not unionized at that time.

AMCU was still new to us, it came later here in Lonmin, from another mine. People were tired of NUM because it was favoring ANC and it is owned by ANC people like Cyril Ramaphosa, whose intentions are always to protect their shares. I remember during our strikes, the RDOs came to us and said we must not go to work because the management have not yet looked at our demands. So that day everyone decided not to pitch, because if we want increase our salaries we must not go to work and strike to show the management that we are serious.

It seems then that the strike was a normal protest, which was initially planned to put pressure on the owners so that they could quickly act on the promise they gave workers in response to their grievances. When asked why the strike took too long, the wives of the deceased said they thought that the longer the strike, the more their husbands were likely to get a positive response. One of them said:

We thought that the longer the strike, our husbands would ultimately get a positive response from Lonmin management, but now we do not know if the commission will help us because we are still waiting for the findings. ${ }^{32}$

\footnotetext{
${ }^{30}$ Lulamile Kali, a mine worker from the Eastern Cape interviewed in Marikana.

31 Marikana miners strike. Retrieved from http://en.wikipedia.org/wiki/Marikana_miners'_strike

${ }^{32}$ Nosakhe Makhamba is one of the women whose husbands were killed during the trage $\overline{d y}$. She was interviewed on 5 November 2014.
} 
What is becoming clear is that the workers were aware of their exploitation and found the wages for the hard work they were doing unacceptable and incapable to meet their subsistence needs and improve their socioeconomic conditions. Because they had been promised with an increase for some time with no action, they had become desperate and angry at Lonmin. Hence, on that day, they engaged in a peaceful demonstration carrying threatening weapons, to show their seriousness, and wanted an urgent intervention and/or a further commitment from Lonmin.

\section{Ubuntu and Its Application in Handling the Strike}

All the interviewees had a clear understanding of Ubuntu, they described the concept as a principle that is in the Constitution and which is inborn- as a right that exists within human beings.

Here in South Africa we have rights and Ubuntu is teaching us to live as one people, this is the reason why we fought, we want to live a better life as well, we also want money.

Ubuntu means to do another person is a pleasant thing, for instance when you have a visitor who is a stranger to you are bound to treat that person with respect and love like you would do with your sister or family members. ${ }^{33}$

Much as they were aware that the Ubuntu principle is in the Constitution, it was interesting to note that they felt that the government misuses Ubuntu by not applying it when it is necessary but only when it suits them. To emphasize this, some of them made reference to the way in which Ubuntu has been applied by government, showing a disjuncture between theory and practice.

I do not think that there is Ubuntu in our government, you only hear government talking about Ubuntu on TV but they do not practice it the way they encourage people. In order for Ubuntu to work it needs good leadership that understands the meaning of this principle. The leadership of this country must not talk about Ubuntu whereas they do not implement it. To me I think it is something that is on paper and not practice, look at our streets they are dirty, people are still poor in our democracy.

They also thought that the manner in which Ubuntu is applied by the current leadership in government is different from how it was applied during Mandela government, which was associated with the character of Madiba, as a father of the nation who wanted to see peace and reconciliation.

During the time of Mandela South Africa was different, it had Ubuntu. When we were going through mourning, we did not even see an ANC Women's League to come to us as women who lost their husbands but Zanele Magwaza of National Freedom Party came to cry with us, the saddest part is that we vote for the ANC each time but they turn against us in times like these. During the time of Mandela, that incident would not have happened because UTata wanted peace. When there is a conflict between people, they should sit down and talk things through ${ }^{34}$.

The government of Mandela's time would have made sure that people get what they deserve. People who sent the police to kill the workers would have been in jail right now. Unfortunately the government of today is not the same, you are on your own, I do not even vote, I keep my vote. We have nothing here, we do not have good services and electricity comes and goes especially on the rainy days. Here you do not even know who is the Mayor, come 2017 when it is voting time the ANC will come to our houses door to door, but look at our streets, they are dirty and that is not Ubuntu. If Mandela was still alive he would have dealt and fired the people who are corrupt in government structures because they think about themselves not about people? ${ }^{35}$

\footnotetext{
33 Anonymous is one of the widows interviewed at the Commission on 5 November 2014.

34 According to Ntombi Msebetsane, also interviewed at the Commission on 5 November 2014.

35 Siyabulela Mtuyedwa, a mineworker from the Eastern Cape interviewed in Marikana.
} 
Although the miners associated Ubuntu with Mandela, who was at the time seen as the man who devoted his later years to reconciliation and trying to unite South Africa's different communities and ending ethnic divisions, they feared that his death would lead the country to lurch backwards as they saw his presence, even in his frailty at the time, to have somehow acted as a guarantee of the few rights they thought they had ${ }^{36}$.

"His death represents a step back in our [campaign for] human rights", said Mr. Nzuza, who concluded that: "The constitution will be overwritten by the powerful".

When asked to describe the workers relationship with Lonmin management, the interviewees said that the workers do not have a relationship with management except for doing the job they are employed to do. They were disappointed and felt betrayed by Lonmin managers who were seen to only focus on their business, not people $^{37}$.This implied that the interviewees saw the shootings as protecting the Interest of Lonmin managers, which they thought was determined to accumulate wealth and profits at all costs. Siyabulela Mtuyedwa added:

People were betrayed by these Lonmin owners, we felt like we were treated like nothing because these people do not care about the lives of the workers but money and international relations. They want to see that they make money but the people who work for them they do not care about them. Even though we were not happy with not getting our $22 \%$ increase, we went back to work because people were already hungry and had to feed their children, others they decided to quit their jobs because they did not want what we are getting.

When they were asked if the Lonmin management had used Ubuntu in addressing the conflict, they all felt that Ubuntu was not applied. They understood Ubuntu as a responsibility of both parties, which can resolve a number of social conflicts including the conflict they were experiencing in Marikana:

If the employers had used Ubuntu to resolve miner's problems, for example, if they really cared, they would have listened to the concerns of employees, and they in turn would have listened to them. Calling the police to kill our husbands does not show Ubuntu ${ }^{38}$.

However, they acknowledged that where Ubuntu was somewhat applied, it was imposed within certain conditions suitable to management. Furthermore, they did not appreciate the fact that it was only after the incident that killed their husbands that Lonmin owners showed some Ubuntu or remorse about what happened. One of the wives indicated:

Although they are now educating our children, we as wives remain poor, we have nothing; our husbands did not only work for their children's education but for the wellbeing of the entire families.

If that day Ubuntu was applied, if the employer came to the people and told them that they cannot pay the money they wanted, there is no way that our husbands would have been killed. Look now, they died for nothing.... Now Lonmin must look after us to show remorse by helping us because we are poor and have nothing. ${ }^{39}$

It seems that the striking miners on that day were ready to negotiate with the owners but Lonmin management who had promised to address their grievances, failed to negotiate with them due to the fact that they had a two year agreement with NUM. The strike happened because they were tired of waiting as their

36 Retrieved from http://www.independent.co.uk/news/world/africa/marikana-mine-strikes-no-peace-and-reconciliation-18months-after-south-african-police-shot-and-killed-34-protesters-9022990.html

37 Lulamile Kali, a mineworker interviewed in Markana.

38 Ntombi Msebetsane is one of the widows interviewed at the Commission on 5 November 2014.

${ }^{39}$ Nosakhe Nokhamba, is one of the widows whose husbands were killed during the massacre, interviewed on 5 November 2014. 
situations were becoming worse. They therefore wanted the owners to tell them the truth about the promises they had given them, and were even ready to negotiate if need be.

Furthermore, throughout, the Ubuntu showed by Lonmin was questionable. First of all, firing of about 12,000 of the 75,000 striking miners for failure to attend the disciplinary hearing on 5 October 2014 which was to be effected after losing labor R700 million ${ }^{40}$ did not show Ubuntu and was considered disgraceful to the nation. There was however, some sense of Ubuntu that was shown. A help desk was established at Lonmin's Andrew Saffy Hospital, which was to assist families with the identification of bodies, and to assist with all the burial arrangements and also offer bereavement counseling (Debate on Marikana Massacre follow-up, 2012). In addition, Lonmin committed to funding education for all the children of workers who lost their lives from primary school to university, on condition that the child is taken to a boarding school chosen by Lonmin. Although these were attempts to meet the bereaved families half way, the wives of the bereaved thought this was not enough to pay back what they lost and to subsisting their daily lives. In addition, it is reported that the Shanduka group which was formed by Cyril Ramaphosa, one of the shareholders, pledged R2 million for the burial of scores of people killed in Lonmin clashes.

\section{Experience of Democracy}

The question of democracy was raised and interviewees were asked to narrate their experiences freedom since the achievement of democracy in 1994. The general response was that democracy is not yet there in South Africa as there are many people who are still in poverty and feeling neglected by government.

Right now we do not feel that we are part of this country, nobody cares about us. We are confused as to what democracy is now, we feel like we are still under the government which oppressed black people. Look, now we do not have our husbands because of this government. We can say we are free but not yet fully free, poor people do not know democracy and I believe democracy and freedom is for those who are privileged, not for us poor people. We do not know it as we are still renting and staying in the "Mkhukho" (informal settlement), we do not even know who our Mayor is, we have never seen him. The ANC does not care about us but you will only see them when they want our votes from us. Even President Zuma, we do not know him, he did not even come to console us when there was a massacre here in 2012. What kind of President is that ${ }^{41}$

The poor living conditions under which people live in this area do not reflect people's expectations, after 20 year of democracy. They blame the ANC led government for the deaths of miners, yet they continue to vote it during elections. They feel as if still under apartheid, not yet free. Some views indicated that communication in this area could be a challenge, probably due to neglect by government officials, who do not disseminate important events and information to the poor, who do not even know their mayor. This was reflected by their unawareness that President Zuma had visited the area just after the massacre. It is important to note that the President had short-changed his trip to Mozambique to visit the site and the victims the day after the massacre ${ }^{42}$. On the first day, he toured the site hearing from the forensic expert who had examined the site and sat at the koppie (hill) where the miners hid from police. On the second day, he went to see the miners' dormitories - including where families stay at an informal settlement. It is surprising then, that those who were directly affected were not aware of this.

\footnotetext{
${ }^{40}$ Malala Justice. Retrieved from http://www.theguardian.com/commentisfree/2012/aug/17/marikana-action-strike-poor-statehaves.

41 Anonymous, is one of the widows interviewed at the Commission on 5 November 2014.

${ }^{42}$ Marikana miners strike. Retrieved from http://en.wikipedia.org/wiki/Marikana_miners'_strike
} 


\section{Reconciliation and Conflict Resolution Strategy}

Another interesting concept to interrogate was the notion of reconciliation, how it is generally understood and in particular, efforts made by the government and Lonmin management to resolve differences between workers and owners, and in the aftermath, to heal the wounds of the victims of the strike. As mentioned earlier, reconciliation is a complex process that takes a long time to consolidate ${ }^{43}$. Referring to the commission, and other strategies used to mediate the strike, the wives of the deceased strikers strongly felt that telling lies about what happened is a serious impediment to meaningful and sustainable reconciliation. One of the wives said:

In my view I think truth is only the way to do reconciliation, both parties should tell the truth and confess that what they did was wrong, so that they are able to correct each other and heal the wounds so that they can move on with their lives. $^{44}$

There is no reconciliation that will happen to mine workers, so long as government is still lying about what happen that day. There is no way that people can reconcile if one party is telling lies ${ }^{45}$. Reconciliation in this country is still far, the leaders themselves are fighting amongst each other. We see on TV that even in our parliament our leaders are embarrassing us where if anybody speaks about what happened in Marikana, they are kicked out the parliament. Furthermore, there is too much corruption and nepotism and the concerns of poor people at work are not even looked at.

"There were also indications that reconciliation is far from happening as there are still racial tendencies in the mines, whereas ethnicism in communities was decreasing", he added.

Furthermore, racism is still a burning issue:

Here in Marikana, there are still places when you go in, the white people decide to leave when the black people enter the canteen for example. As well there at the mine there is racism, when you start the employment with the white person with in the five months he gets promotion and become your senior, or even when they arrive after whether they are educated or not, they get promotion, and I think white people here are more favored than black people, unlike in the East London where I am coming from. Us black people here we live together nicely whether you are the Shona, Tswana, Xhosa we live together nicely ${ }^{46}$.

\section{Summary}

Both the accounts given by interviewees, and literature related to the event, indicate that on one hand, the strikers had very valid grievances as the amount of money they were being paid for the job they were doing under harsh conditions cannot be accepted, it is simply criminal. On the other hand, by engaging in unlawful behavior and activities to put pressure on management seemed to have diverted their attention from the unfair treatment they were receiving from greedy employers and investors at the expense of workers (Nco Dube, 2012). However, what comes out clearly is that no single party should be held accountable and responsible for the shooting of striking miners, but all parties involved (Lonmin, Unions, government and police, and the media). The most feasible conclusion could be that the shooting was a series of blunders, wrong decisions, indecisiveness and incompetency, greed and opportunism on the part of Lonmin, striking workers, police, government, media, unions and politicians in general. Blaming it on a single group cannot be fair; it can be read as opportunism or ignorance (Nco Dube, 2012).

\footnotetext{
${ }^{43}$ Lulamile Kali, a mine worker from the Eastern Cape interviewed in Markana.

44 Nosakhe Nokhamba, is one of the women whose husbands were killed during the tragedy. She was interviewed on 5 November 2014.

${ }_{45}$ Ntombi Msebetsane, is one of the women whose husbands were killed during the tragedy. She was interviewed on 5 November 2014.

${ }^{46}$ Lulamile Kali, a mine worker from the Eastern Cape interviewed in Markana.
} 
Although the above literature has indicated that violent strikes in South Africa have occurred since the 1940s, not much has been done by mine owners and government to show compassion or humanity to workers by offering them decent wages that matches the job they do. Lonmin management should therefore be held accountable and responsible for the strike. They should not have allowed things to go that far, they should have come to the striking miners themselves, not to send the police. Furthermore, Lonmin should have paid workers fairly long ago, especially because they had promised them an increase. A fair employer would never pay their workers, who risk their lives daily under horrible conditions, R4,000 a month while paying a CEO over R29 million a year (Dube Nco, 2012). This cannot be accepted, it is criminal and unjustifiable! Furthermore, because the Lonmin Chief Executive Officer was hospitalized for a serious illness two days before the massacre, they still had no coherent plan to end the impasse.

The unions should also be held accountable, for failing to convince workers to make reasonable demands, and to protect their interests for such a long time. The tactics of violence and intimidation used by AMCU to gain membership were improper. While indeed R12,500 was a fair demand, it was totally unrealistic to expect an employer to jump workers from $\mathrm{R} 4,000$ to that amount in one go. A responsible union would have negotiated for an incremental increase that would have put workers in that bracket over a period of time. In fact it is the unions themselves, NUM included, that had allowed this kind of abuse. AMCU, on the other hand, thought that the only way to gain popularity would be to appear more radical than NUM by acting opportunistically and recruiting disgruntled NUM members. While they managed to mobilize them on unrealistic demands, they failed to condemn the violence. In response, NUM forgot about the interest of their members and concentrated only on protecting their "territory" (Dube Nco, 2012). As a consequence, NUM lost all credibility, not only because they had no cogent plan to end the strike, but also because they refused to get out of police armored vehicles to address workers on the sad day. Because AMCU was also organising among poor workers and their shack settlement communities, who saw the strike not just as a union matter, but against the state and the haves, not just a union matter. Hence, Joseph Mathunjwa, an AMCU leader, told workers: "We're going nowhere. If need be, we're prepared to die". This Marikana tragedy is a story of a trade union that cosied up to big business; of an upstart and populist new union that experienced real frustration to establish itself; and of police failure.

Government and police: When the first signs of violence surfaced at Lonmin and 10 people were murdered prior to 16 August, the government didn't seem too sure what to do. It seems that effective policing and a responsive executive was lacking. The police should have been prepared and made efforts to clamp down on the illegal gatherings and disarm the miners from the onset. Even though the police were aware that AMCU was already organising in other mines in the region, where violence was also flaring, the police failed to gather intelligence to prevent recurrence ${ }^{47}$. The police were wrong to utilize maximum force as a first attempt to disperse the crowd, even if it was to protect themselves. This is a tactic that was used by apartheid during the liberation struggle to disperse toy toying crowds and should not be encouraged in a democracy.

Furthermore, the fact that most of the people were shot at the back indicate that they were running away, which opposes the claim made by the police. Even more shocking was the fact that the arrested miners were later charged with murder of their own colleagues who were shot by the police. So, if the police had handled the matter well from the onset, there probably wouldn't have been armed miners at that koppie. Instead, they

${ }_{47}$ Retrieved from http://www.theguardian.com/commentisfree/2012/aug/17/marikana-action-strike-poor-state-haves 
claimed that the shooting was in self-defense due to the fact that the miners were in possession of a pistol which was taken from an officer that was bitten to death earlier in the week.

\section{Theorizing the Marikana Tragedy}

Since the Durban strikes of 1973, South Africa has come a long way in building up institutions through which democracy and social justice can be achieved. Although there were other industrial strikes after 1973, the unprotected strikes in Lonmin platinum mines and of farm workers in De Doorns are an indication that "spontaneous" revolt in South Africa has now extended to the industrial sphere, and the unintended consequences associated with these protests demonstrate the weakening of the labor relations system which opposes one of the victories of the National Democratic Revolution (NDR) (Mbeki, 2012).

Twenty years into democracy, it is surprising that the approach used by citizens as a way of raising collective problems to government is the same approach that was used in violent protests during the liberation struggle. The tragedy reminds us of the dangers of state-induced violence, which still exist even in our democracy, as well as of the increasing importance of responsible and effective public order policing as was the case in the violent protests such as the 1973 Durban strikes or struggle conflicts such as Sharpville and Boipatong Massacres. In this regard, the Marikana tragedy could demonstrate a clear example of the ANC government stepping squarely into the shoes of its predecessors - apartheid's Nationalist Party and Smuts' South African Party — by acting to secure the profits of mining capital through violence.

As indicated in accounts given above, most of the drill workers at Lonmin are Xhosas railed in from the Eastern Cape into an area which is largely Tswana speaking - to heighten exploitation at the coalface of drill workers. The fact that the majority of recruiters are a product of migrant labor system resembles the Bulhoek and Bondelswaarts massacres which occurred as a result of setting up forced recruitment over southern Africa that led to the dreaded migrant labor system, the compounds and the dompas system. Throughout the colonial and apartheid legacy, successive governments ensured a cheap, divided and compliant labor force for the mines. In this regard, Lonmin epitomizes the make-up of the new elite in South Africa—old white capital garnished with a sprinkling of politically connected blacks in the name of Black Economic Empowerment (BEE) ${ }^{48}$.

The Marikana massacre is the most disturbing episode in the history of our democracy that marks a decisive turning point in the liberation alliance around the ANC - particularly COSATU, and in the country's post-apartheid history. Although COSATU's moral authority was enhanced after 1994, as the federation continued to be the most organized moral voice among the working class, its focus seem to have changed. Anyone who had a campaign - whether challenging the limitations on media freedom or fighting for renewable energy - sought out COSATU as a partner. But today, COSATU's links with the working class is very weak. It is almost intuitive that we consider the notion of a worker as someone working for a clearly defined employer, on a full-time basis, in a large factory, mine or supermarket. Indeed classical industrial trade unions were forged by workers in large factories and plants and industrial areas. This was the case in many countries where such unions won the right to organize and bargain collectively — and was also the case in South Africa, when a new wave of large unions formed industrial unions after 1973's Durban strikes. Going along with this structure of work were residential spaces of townships which were organized by capitalism in apartheid South Africa from the 1950s, which was increasingly accepted as the de facto existence of a settled urban proletariat - which intensified from the early 1970s — and built the matchbox brick houses in the townships of the apartheid era

\footnotetext{
${ }^{48}$ Leonard Gentle. Retrieved from http://links.org.au/node/2997
} 
such as the Sowetos, Kathlehongs, Tembisas and the like. So despite the negative effects of urbanization and its migrant labor system, the working class was organized into large industrial sites and brick houses in large sprawling townships.

Since the 1980's, when the neoliberal phase of capitalism kicked in this situation and mining in general changed and the living conditions of workers deteriorated and workers exploitation became more pronounced. It would then not be surprising to think that 20 years ago, the underground mineworkers of Lonmin would have lived in a compound provided by and policed by the company, compared to how rock drill workers live today, in a shanty town nearby the mine. Also, today much of the serious hard work underground is done by workers sourced from labor brokers. As indicated by interviewees, these are the most exploited and insecure workers who work the longest hours and most flexible arrangements. It is even possible today to own a mine and not work it yourself but to contract engineering firms like Murray and Roberts to do the mining for you ${ }^{49}$. Lonmin has exploited these divisions, which were also exacerbated by use of the old mining industry strategy of recruiting along ethnic and regional divisions.

By way of contrast the dominant trade unions in South Africa have largely moved upscale-towards white-collar workers and away from this majority. Today the large COSATU affiliates are public-sector white-collar workers - the South African Democratic Teachers' Union (SADTU), the National Education, Health and Allied Workers' Union (NEHAWU) and the unions among white-collar workers in the state-owned utilities - Telkom and Communication Workers' Union (CWU) and Transnet and the South African Transport and Allied Workers Union (SATAWU). The lower level blue-collar workers seem to have been left behind, as they have remained in labor brokers and in services that have been completely outsourced-like cleaning, security etc. They therefore do not fall within the bargaining units of the Public Sector Bargaining Council. It seems then that capitalism and the exploitation of workers is still continuing in South Africa, not only in the mining sector but for blue collar workers in general.

We could safely state that the anger of the miners is a deep-seated anger at mine management that is progressively being directed at the compliance and failure of their union leadership to defend and represent worker interests ${ }^{50}$. As demonstrated above, it is true that enriched mine owners with the experience of BEE co-option have contributed to a wedge between "reasonable" union leaders and the workers. They have enticed the unions into sweetheart relations dividing them from the worker ranks-and-files.

\section{Reconciliation Strategies: Lessons from TRC}

While Lonmin and government tried to some extent, to reconcile victims of the Marikana tragedy, the people interviewed felt that the strategies used were either ineffective or very poor, partly as a result of failure by government to implement some of the TRC recommendations and failure to use Ubuntu as a conflict resolution strategy. Immediately after the tragedy, the Marikana victims, many of whom had lost breadwinners, were promised reparations, just as their TRC counterparts were. But as indicated by the bereaved families interviewed above, many apartheid victims are still awaiting meaningful rehabilitation measures and compensation promised nearly 12 years ago after the final TRC report was received in Parliament by the then-president Thabo Mbeki.

Furthermore, during the commission itself, victims appeared to struggle to make their voices heard and to

\footnotetext{
${ }^{49}$ Leonard Gentle, director of the International Labor Research and Information Group (South Africa). Retrieved from http://links.org.au/node/2997

50 Amandla editorial comment in http://www.guardian.co.uk/commentisfree/2012/aug/17/marikana-action-strike-poor-state-haves
} 
participate fully in the proceedings due to lack of funding that would have afforded them top representation. This was against the police ability to access state money, that made it possible for them to afford to hire a range of top skills. Consequently, victim participation was somewhat constrained and NGOs such as Seri tried to fend for victims on a shoestring budget, to the extent of having to resort to courts to fight this battle. The role of Seri reminds us that the improvement of socio-economic rights of all South Africans is fundamental to the realization of national reconciliation.

Moreover, police reports submitted to the commission seem to obfuscate the truth of what happened instead of reveal it. There was no real acknowledgement or accountability from the police force that clearly and brazenly indicated that they had overstepped their mark, by killing scores of protesting miners in a military-style show of brutal force. Consequently, the Marikana commission has not yet convinced onlookers that it will be able to deliver the kind of truth that could help victims and society at large understand what precisely happened or how police brutality of this kind may have been averted. As indicated by the victims, lies are the major detriment to reconciliation, conflict resolution and healing.

Although there are doubts about the role of the Commission, it is clear that the striking mineworkers will always be blamed for being violent and painted as savages. The fact is that heavily armed police with live ammunition brutally shot and killed 34 mineworkers, and injured many more. This was not the action of rogue cops but was a result of decisions taken at the top of the police structures to protect the interests of capital. Prior to the event, the police responded with force and came armed with live ammunition. They erected roadblocks, detours and barricades in areas for the public's protection. They behaved no better than the apartheid police forces in events such as the Sharpeville, 1976 Soweto uprisings and 1980s protests where many Africans were killed.

From the accounts given, it is clear that justice for victims is far from being achieved, which would ensure that the TRC legacy is carried forward and that it had made a real difference in the way South Africa is governed. Key to the TRC recommendations were a whole range of carefully detailed structural and institutional reform measures, which needed to be carried forward by different ministries such as land reform, justice, safety and security, police, the military and so forth. This tragedy, therefore, reminds South Africans about the importance of victim-centered justice and of incisive truth-recovery in the aftermath of mass violence, both of which were crucial lessons of the TRC process, which are now in danger of being forgotten.

The accounts given by victims above indicate that the Marikana tragedy in general represented a temporary lapse of the rule of law rather than the failure of an entire system on the scale that apartheid represented. It illustrated that there has been little or no systematic effort made by the South African government to account itself against the TRC recommendations. Clearly, as a maturing democracy 20 years down the line, amnesty is no longer an option, people who voted for the democratic government are impatient and want drastic improvements in their socioeconomic conditions through jobs, education and skilling, houses, etc.

\section{Application of Ubuntu Philosophy}

Since 1994, both Presidents Mbeki and Zuma have often invoked Ubuntu as an ethic that should guide government policy. Given the fact that Ubuntu philosophy is pronounced in the preamble of the Constitution, it is fair to assess the way the state has responded to the Marikana tragedy. What has become apparent from the accounts given above, is that despite government voicing adherence to Ubuntu as a foundational value, its reactions to the Marikana tragedy have displayed too little of Ubuntu. As indicated by the interviewees 
responses, the government only show Ubuntu selectively, when it suits them.

Although there is generally much controversy about how Ubuntu should be precisely understood, there are some themes that stand out. The ethic associated with Ubuntu clearly instructs one to develop one's humanness, to live a genuinely human way of life by prizing communal relationships with others. For one, this means identifying with others, which involves being close, belonging, participating and experiencing life which is bound up with others, while considering oneself as part of the larger group. Obviously, both management and government chose to distance themselves from the workers. They did not act timeously to protect the workers but were preoccupied with protecting their own interests. The fact that the workers were subjected to harsh working and living conditions, both Lonmin management and government did not exhibit ubuntu, they failed to share the workers way of life or to care for their quality of life. ${ }^{51}$ Even worse, firing workers during the strike was considered disgraceful to the nation and entrenched the impunity of white monopoly capital which does not care about the plight of the poor ${ }^{52}$.

By failing to negotiate with workers, both Lonmin management and the state exhibited little Ubuntu. At least, it was not the kind of Ubuntu associated with Madiba which respects humanity and freedom. In his own words, Madiba said "... for to be free is not merely to cast off one's chains, but to live in a way that respects and enhances the freedoms of others". The humility that Madiba demonstrated in his life by seeing the good in each person irrespective of race and by making everyone feel better about them; by seeking unity than revenge, honesty and understanding rather than the naked exercise of power. A person with Ubuntu is open and available to others, does not feel threatened that others are able and good; for he or she has a proper self-assurance that comes from knowing that he or she belongs in a greater whole and is diminished when others are humiliated or diminished, when others are tortured or oppressed, or treated as if they were less than who they are. If Lonmin management understood this principle, perhaps the tragedy would have been avoided.

Even after the tragedy, reconciliation strategies used were very poor and had little Ubuntu. If Ubuntu was used, as the concept often associated with the idea of reconciliation in Africa, which includes cooperation, forgiveness, healing and willingness to share (Gutto, 2006, p. 141), then reparation would have led to the raising up and restoration of that which was ruined; repairing that which was damaged; re-joining that which is severed; replenishing that which was depleted or lacking; strengthening that which was weak; setting right that which was wronged; and making secure that which was insecure or undeveloped. Even if the state wanted to show Ubuntu during the massacre, it wouldn't have been easily manifested in the face of gross injustices, especially in recognition of the state's role during the shooting. Throughout the strike, little was done by the state to set right what was wrong or to reconcile differences between workers and the police.

Furthermore, the manner in which police action was carried out prior to the event, who came forcefully, with live ammunition had no Ubuntu, and this indicates behavior that was no better than the apartheid police forces during the liberation struggle such as Sharpeville, 1976 Soweto uprisings and protests of the 1980s where many protesting Africans were killed. From the conflict perspective, the Marikana massacre was an attack on workers in defence of white privilege - specifically the mining house, Lonmin. The killings alone, mark the end of the illusion of a moral high ground occupied by the ANC and the completion of its transformation

\footnotetext{
51 Thaddeus Metz is Humanities Research Professor of Philosophy at the University of Johannesburg. A-rated UJ Prof comments on Marikana. Retrieved from http://www.uj.ac.za/ (This is a mildly revised version of no Ubuntu in Marikana Hearings. New Age. 16 August 2013, p. 19).

52 Marikana miners strike. Retrieved from http://en.wikipedia.org/wiki/Marikana_miners'_strike
} 
into the governing party of big capital. The tragedy also represents failure of government leadership: Ministers of Labor and Minerals Resources who was absent during the entire episode; Minister of Police who maintained that this was not political but a mere labor dispute and defends the actions of the police; and failure of the President of the country who failed to mobilize the government and its tremendous resources to immediately address the concerns of the mineworkers and their bereaved family members.

Because of this, the people interviewed did not associate the current government with Ubuntu, and thought that it had departed from what Madiba fought and went to prison for, so that there could be reconciliation - an end to apartheid, racism, injustice, economic exclusion and landlessness. The Marikana tragedy demonstrates that the hand of reconciliation that Madiba so generously extended was being undermined by a lack of commitment to transformation by the very same people who maintained, collaborated with and benefitted from apartheid who profess to love him dearly. This indicates that if love for Madiba was realistic, it should have been expressed in deeds, through acts of humility and restorative justice for the victims of the Marikana tragedy (Dube, 2013).

\section{Failure by the State to Display Ubuntu}

It seems then that the state failed to display Ubuntu on the following counts ${ }^{53}$ :

(1) Immediately after the tragedy, the state was quick to help bury the dead and to offer counselling to their families. Instead, the state distanced itself from citizens and expressed indifference toward them. An Ubuntu-oriented state would not hesitate to express sympathy for the plight of innocent families as well as to adopt a systematic plan to do all it can never to repeat the traumatic event.

(2) During the Farlam Commission, the state showed no respect for African cultural values. Its initial inclination was to support attendance by families only for the first session of the investigative hearings, with no legal requirement to do anything at all in this respect. It was only after public outcry, that the Minister of Justice Radebe backtracked. But even so, the state allowed only one family member to attend, which opposes the African cultural value system that she cannot travel alone while in mourning. A state guided by Ubuntu would have readily supported family attendance at the investigative hearings, as a way to foster reconciliation with the police. It would have been quick to fund legal representation for the miners and their families, as the truth about what happened at Marikana is unlikely to be revealed if there are lawyers to represent only one side, the police.

(3) The National Police Commissioner Phiyega ignored wailing families during hearings, but entertained and justified the police position as its commissioner. She never attempted to acknowledge or comfort the victims or the aggrieved family members. When asked at the Commission why she did not reach out to distraught families, she is reported to have snapped, "I am not here for that. I am here for the commission and the commission only".

(4) As stated earlier, while the state paid for legal representation on the part of the police, it refused to pay for legal representation for the strikers and their families, citing no legal requirement to do so. Miners have had to go to court to try to force the state to pay for expensive advocates, without success, and ultimately had to appeal to the Constitutional Court to make the state do so.

(5) Even if the state was justified to use maximum force in response to the aggression of striker aggression, the state did not thoroughly explore how it would avoid a similar occurrence in the future. It did not seek out non-violent measures in response to upheaval. Therefore, the recurrent appeal by state officials to the presence

\footnotetext{
53 Adapted from Prof. Alexandra research. Retrieved from http://links.org.au/node/2997
} 
or absence of a rule for their actions does not comport with an Ubuntu ethic. It demonstrates an immoral action which is not expected of state officials, whether the rules allowed them to do so or not.

If Ubuntu was applied, the right thing for state officials would be to reconstruct community, and to foster reconciliation. If prizing relationships of sharing and caring is what matters, then the state's central response to conflict should have been to repair broken relationships and to do so in light of a transparent understanding of how the two parties should treat one another in order to resolve the conflict.

\section{Conclusion}

Although violent strikes in South Africa have occurred since the 1940s, what has come out is that the Marikana massacre and other strikes in the mines, as well as other recent service delivery protests around the country are a direct response to the structural conditions in South Africa that need to be radically addressed. The shootings and the general instability exposes South Africa's structural weaknesses where poverty, inequality and unemployment lie at the heart of world's top two most unequal societies, following Brazil (Justice Malala, 2012).

The Marikana tragedy has provided valuable insight into new upsurges of struggles in South Africa over the last few years. It has demonstrated the consequences of not addressing the triple challenges faced by the working class in South Africa as the country experiences maturing democracy. So long as the triple challenges facing the country are not addressed, the people will continue to take matters into their own hands in seeking redress for conditions they hoped for at the onset of democracy. The level of violence that goes with it demonstrates deep divisions, inequalities and polarization within the South African society. Twenty years into democracy, not much has changed for the majority black South Africans who voted for a democratic government in 1994. As noted above, mineworkers are a section of South Africans who still live in extreme conditions of poverty, in squalor squatter camps without basic services. Most of them are unemployed and those who lucky, are often employed through labor brokers and informalized without decent work conditions.

It is clear that the challenges brought about by the widening gap of inequalities between a white minority joined by a small black elite, while the majority of blacks are enduring high unemployment, inadequate housing, health care and education will not be eliminated anytime soon, so long as vulnerable workers are not paid decent wages and their living conditions are not improved. It is the negative consequences of these challenges, that had brought a lot of frustration and anger to the workers, which had been expressed in various violent protests by citizens, including workers in the Lonmin mines, as the country experiences maturing democracy. The challenge is now on government to ensure that when they speak of a developmental country, they indeed address the triple challenges and provide reasonable strategies on how to eradicate them. Although, it won't be easy, the government needs to urgently implement radical socioeconomic transformation.

Indeed, the Marikana tragedy awaken us to the reality of the time bomb that has stopped ticking, which has in fact exploded as "Africans are now fighting for bigger slice of the mineral wealth of the country ${ }^{54}$ a position usually taken by the youth wing of the ANC to nationalize the country's mines and farms. Under the current conditions where government is adamant about taking responsibility and accountability for the massacre, it can be concluded that the striking mineworkers will always be blamed for being violent and will always be painted as savages. This is against undisputed evidence that indicated that heavily armed police with

\footnotetext{
${ }^{54}$ Retrieved from http://www.theguardian.com/commentisfree/2012/aug/17/marikana-action-strike-poor-state-haves
} 
live ammunition brutally shot and killed 34 mineworkers, and injured many more. The fact that they erected roadblocks, detours and barricades in areas for the public's protection, was not just the action of rogue police officers but was a result of decisions taken at the top of the police structures to protect the interests of capital and the ruling party at the expense of the majority of people whose conditions have not changed 20 years into democracy.

It is correct to state that the Marikana tragedy and its aftermath, demonstrate a very good test case for the effectiveness of the reconciliation agenda in South Africa, which was initiated by the TRC process soon after the attainment of democracy. The strikes in Marikana indicate that reconciliation and nation building in SA will remain a challenge for many years to come. Some have argued that the manner in which the massacre was carried out represents shallowness of national transformation in this country, which has left a blood-stain on the new South Africa. From the conflict perspective, it is regrettable noted that the reconciliation strategies used both by the government and mine owners, to address the worker's needs, as well as to resolve the strike and its aftermath, still serve the interests of capital; and have departed from the application of Ubuntu-an African solution to solving problems - as would have been applied by Madiba. Even during the strike in Marikana up to its aftermath, where many lives were lost, it seems that not much has been done by government, owners of capital and the media to show compassion or humanity to workers by offering decent wages that matches the job they do. Even reporting by media analysts and commentators seemed to have forgotten all about the people who actually died and their families.

Resolving the consequences of the tragedy on its own is a complex process that does not mean forgetting or trying to bury the pain caused, but requires truth telling, forgiveness and healing which is hoped to be achieved by the Commission. For the process to be meaningful and sustainable, it will require the application of appropriate strategies grounded in Ubuntu principles to resolve disagreements in a peaceful manner. Forgiveness of the perpetrators, whether the police or Lonmin management for pushing the workers this far, will require the application of humility by all parties involved that is found in the spirit of Ubuntu we are all endowed with as human beings.

In reviving the philosophy of Ubuntu and its principles in our lives, there is a need to understand that we are what we are because of our fellow South Africans. Mine owners are what they are because of the workers. For without Ubuntu and thinking of the other, our efforts for peaceful co-existence, and for creating this united, non-racial and non-sexist society will be in vain and true reconciliation and freedom will only remain as a dream. In order to establish sustainable peace in Marikana, there must be reconstruction and reparation measures that may require finding ways of discovering humanity by utilizing Ubuntu as a philosophical outlook that could inspire a new direction in thinking about relations between humans ${ }^{55}$. The rich must always remember that they are rich also because of the toil and sweat of other South Africans, many of whom happen to be poor. As we know, the system of apartheid has ensured that even today, twenty years after our democracy, wealth is still distributed along racial lines. Accordingly, it is the duty, not merely of government but of all South Africans, to unite against poverty and racial discrimination. In this way, we shall achieve social harmony and advance towards the achievement of national reconciliation and peaceful coexistence.

While it is acknowledged that there are many flaws in implementing reconciliation strategies, including addressing challenges such as violence and economic freedom, it does not mean that achieving meaningful

55 Retrieved from http://www.sahistory.org.za/topic/rand-rebellion-1922 
reconciliation is impossible as none of the challenges are irresolvable. Resolving conflict requires national commitment and a concerted effort on the part of all South Africa's citizens to amicable resolve challenges while tolerating each other's differences.Many conflicts in today's world could be resolved by infusing Ubuntu or Botho into their body politics, as a recipe for peaceful coexistence in a diverse society such as South Africa.

Reconstruction in Marikana may require finding ways of discovering our humanity by utilizing Ubuntu as a philosophical outlook that could inspire a new direction in thinking about relations between humans. Ubuntu would allow all parties to work with the vast richness if indigenous knowledge and learn about all the positive knowledge of humanity to be able to break the binary concepts of what informs the intellectual culture of neoliberalism, the so called modernity and scientific method.

Government officials must show political will, which will ensure that the workers are treated with humility, and are provided with better working conditions and can afford a safe living environment just like white collar workers. Although there is clear indication that these problems need to be eradicated, the big question is what is the real problem in our country if we have a clear programme of reconciliation? As part of building a united South African nation we have to mark every day as a day of struggle against poverty, inequalities and racism, discrimination, abuse, and other backwards attitudes.

True reconciliation can only be possible if social interaction is regulated through the rule of the law so as to prevent certain forms of violations of rights from recurring. To achieve this, inappropriate behavior has to be condemned (irrespective of who is responsible); the truth about how violations were committed should be uncovered; and people should be discouraged from repeating these offences by setting up appropriate institutional and social safeguards; prosecute where possible; and learn from past mistakes (Hamber, 2002). Most importantly, as indicated in the TRC report, reconciliation requires a commitment, especially by those who benefitted and continue to benefit from past discrimination, to transformation of unjust inequalities and dehumanizing poverty ${ }^{56}$.

Indeed, justice and reconciliation cannot be separated; both contribute to peace and stability (Hamber, 2002). For justice and reconciliation to be achieved, there needs to be a dialogue where measures that should be adopted in the reconciliation process and conflict resolution processes should be debated and determined. Priority in South Africa must also be to strengthen the national legal system that deals appropriately with the perpetrators of the violations, and to make appropriate reparations to the victims. To date, perpetrators have overwhelmingly remained unpunished for the crimes committed, which stifles the need for healing and reconciliation. These situations must be rectified urgently, in order to achieve negotiated peace and complete the reconciliation agenda.

\section{References}

Alexander, P., Sinwell, L., Lekgowa, T., Mmope, B., \& Xezwi, B. (2012). Marikana: A view from the mountain and a case to answer. South Africa, Johannesburg: Jacana Media Ltd.

Bloomfield, D., Barnes, T., \& Huyse, L. (Eds). (2003). Reconciliation after violent conflict: A handbook. International Institute for Democracy and Electoral Assistance: Sweden.

De Grunchy, D. (2002). Reconciliation. Cape Town: David Phillip.

Debate on Marikana Massacre follow-up: Were victims fleeing tear gas? (2012). Retrieved from http://lists.fahamu.org/pipermail/debate-list/2012-August/031369.html

Du Toit, F. (2013). Marikana victims deserve justice. Retrieved from http://www.iol.co.za/capetimes/

56 TRC final report vol1 ch1 par 63. 
Dube, N. (2012, October 4). The class wars. Retrieved from http://ncodube.wordpress.com/2012/10/04/the-class-wars/

Dube, N. (2013). Open letter to all two-faced apartheid beneficiaries. Retrieved from http://ncodube.wordpress.com/

Fogel, B. (2013, January 14). De Doorns: A community enveloped by fear and anger. The Daily Maverick. Retrieved from http://www.dailymaverick.co.za/article/2013-01-14-de-doorns-a-community-enveloped-by-fear-and-anger\#.Vcqt4tJAU9M

Fogel, B. (2013, January 30). Tensions remain following dismissals of workers in De Doorns. The Ground Up. Retrieved from http://groundup.org.za/content/tensions-remain-following-dismissals-workers-de-doorns

Gutto, S. B. O. (Ed.). (2006). Towards a new paradigm for pan-African knowledge production and application in the context of the African Renaissance. International Journal of African Renaissance Studies: Multi-, Inter- and Transdisciplionarity (IJARS), 1(2), 306-323.

Hamber, B. (2002). Ere their story die: Truth, justice and reconciliation in South Africa. Sage: Institute of Race Relations.

Justice Malala. (2012, August 17). The Marikana action is a strike by the poor against the state and the haves. Retrieved from http://www.theguardian.com/commentisfree/2012/aug/17/marikana-action-strike-poor-state-haves

Mbeki, T. (2012). Celebrating ANC President Oliver Reginald Tambo. Proceedings of the Celebration of the Centenary of the $A N C$, University of Fort Hare, Alice.

Mills, C.W. (1956). The power elite. Oxford University Press, USA.

Motsei, M. (2007). The kanga and kangaroo court: Reflections on the rape trial of Jacob Zuma. Johannesburg: Jacana Media.

Motsheka, M. K. (2012). Ubuntu: The African philosophy of origins and being. Kara Heritage Series No. 2. Kara books: Pretoria.

Nco Dube, N. (2012). Marilkana: An orgy of opportunism in the face of disaster. Retrieved September 18, 2012, from http://www.thoughtleader.co.za/ncodube/2012/09/15/marikana-an-orgy-of-opportunism-in-the-face-of-disaster/

Vecchiatto, P. (2013). De Doorns farm workers gather to demand increase in minimum wage. Business Day Live. Retrieved from http://www.bdlive.co.za/

Wolff, J. (n.d.). Karl Marx. Retrieved April 29, 2011, from http://plato.stanford.edu/entries/marx/ 